Asian J. Med. Biol. Res. 2016, 2 (4), 532-540; doi: 10.3329/ajmbr.v2i4.30993

\author{
Asian Journal of \\ Medical and Biological Research \\ ISSN 2411-4472 (Print) 2412-5571 (Online) \\ www.ebupress.com/journal/ajmbr
}

\title{
Article \\ Morphological characterization and assessment of genetic parameters of NERICA mutant rice lines under rainfed condition
}

\author{
Md. Nuruzzaman ${ }^{1}$, Lutful Hassan ${ }^{1 *}$, Shamsun Nahar Begum ${ }^{2}$ and Md. Monjurul Huda ${ }^{1}$ \\ ${ }^{1}$ Department of Genetics and Plant Breeding, Bangladesh Agricultural University, Mymensingh, Bangladesh \\ ${ }^{2}$ Plant Breeding Division, Bangladesh Institute of Nuclear Agriculture (BINA), Mymensingh, Bangladesh \\ *Corresponding author: Professor Dr. Lutful Hassan, Department of Genetics and Plant Breeding, Bangladesh \\ Agricultural University, Mymensingh-2202, Bangladesh. E-mail: lutfulhassan@ yahoo.co.uk
}

Received: 17 October 2016/Accepted: 01 November 2016/ Published: 29 December 2016

\begin{abstract}
An experiment was conducted to evaluate thirty one NERICA mutant rice genotypes (twenty eight NERICA mutant lines along with three parental lines) of advanced $\left(\mathrm{M}_{4}\right.$ and $\left.\mathrm{M}_{5}\right)$ generations for morphological characters and genetic parameters assessment in aus season, 2014 at the experimental field of Biotechnology division, BINA, BAU Campus, Mymensingh-2202 following Randomized Complete Block Design (RCBD) with three replications. The genotypes differed significantly for all the traits viz., days to flowering $\left(1^{\text {st }}, 50 \%\right.$, $80 \%$ ), days to maturity, plant height, total tillers and effective tillers hill ${ }^{-1}$, filled and unfilled grains panicle ${ }^{-1}$, 100 -seed weight $(\mathrm{g})$ and yield plant $^{-1}(\mathrm{~g}) \cdot \mathrm{N}_{1} / 300 / \mathrm{P}-9-5$ had maximum yield plant ${ }^{-1}$ and $\mathrm{N}_{4}$ parent had minimum yield plant ${ }^{-1}$. All the parental lines showed less yield compared to other mutant lines. The phenotypic coefficient of variations (PCV) were higher than genotypic co-efficient of variations (GCV) for all the traits studied indicating that they all interacted with the environment to some extent. All the traits studied expressed moderate to high heritability estimates ranging from 43.68 to $92.87 \%$. High heritability along with high genetic advance was noticed for the traits, number of filled grains panicle ${ }^{-1}$, number of unfilled grains panicle ${ }^{-1}$ and plant height.
\end{abstract}

Keywords: NERICA; mutant lines; morphological characters; genetic parameters

\section{Introduction}

NERICA is a new drought tolerant rice variety introduced by the ministry of agriculture for growing in drought prone areas of Bangladesh. The term NERICA stands for New Rice for Africa, an extended family of some 3000 siblings. NERICA is the product of interspecific hybridization between the cultivated rice species of Africa (O. glaberrima) and Asia (Oryza sativa). Rice grain yield is a quantitative polygenic character and highly influenced by environment. Extent and significance of association of yield with yield components should be considered, while determining the selection criteria of germplasm on the basis of available genetic variation. The success of breeding program also depends on the amount of genetic variability present in the population and extent to which the desirable traits are heritable. Different morphological traits play very important role for more rice production with new plant type characteristics associated with the plant yield. Phenologicalproperities of rice also associated with the yield potential of the different rice varieties that further involved in rice breeding program (Shahidullah et al., 2009). Study of genetic divergence among the plant materials is an important tool to the plant breeders for an efficient selection of the diverse parents for their potential use in a rice breeding program for the improvement of the rice production. The term rainfed is used to describe farming practises that rely on rainfall for water without any artificial irrigation. Development of improved rice varieties with stress tolerance traits from introduced varieties could significantly increase productivity (Mzengeza, 2010). NERICA varieties have high yield potential and short growth cycle. Several of them possess early vigor during the vegetative growth phase and this is a potentially useful trait for weed competitiveness. Likewise, a number of 
them are resistant to African pests and diseases, such as the devastating blast, to rice stem borers and termites. They also have higher protein content and amino acid balance than most of the imported rice varieties (WARDA, 2008).

Though its cause of low productivity in Bangladesh is still unrevealed, the farmers found low tiller number, weak and fragile stem could be the important morphological characters that compromised the yield (reported in a discussion meeting organized by UBINIG, 28 September 2012). Moreover, the scientists in the discussion meeting assumed that the low productivity could be due to climatic change and soil variation compared to its origin. For this reason mutation is applied to produce mutant lines to improve yield of NERICA lines in Bangladesh.

Mutants have made it possible to identify critical elements for developing high yield potential varieties exhibiting desirable traits such as semi-dwarfism, early maturity, greater number of panicles plant ${ }^{-1}$ and increased fertility. The technique has been successfully utilized by Bangladesh Institute of Nuclear Agriculture (BINA) and many other research institutes on different crops (Das et al., 1999; Azad et al., 2012).

Therefore, the present experiment was conducted to evaluate thirty one mutant rice lines for morphological traits and to assess the genetic parameters of the NERICA lines to screen out best performing lines and traits with high heritability and genetic advance for developing high yielding new rice varieties.

\section{Materials and Methods}

\subsection{Experimental materials}

Thirty one NERICA rice genotypes (twenty eight mutant lines along with three parents) of advanced generations $\left(\mathrm{M}_{4}\right.$ and $\left.\mathrm{M}_{5}\right)$ were used. Seeds of the rice genotypes were obtained from Bangladesh Institute of Nuclear Agriculture (BINA), BAU Campus, Mymensingh-2202. The experiment was conducted in aus season 2014. The list of the genotypes is present in the Table 1 .

\subsection{Field experimentation and management}

\subsubsection{Seedbed preparation and sowing of pre-germinated seeds}

Seed bed was prepared by raising soil up to $5-10 \mathrm{~cm}$ from the field surfaces followed by puddling. Before puddling cow dung was applied @ $2 \mathrm{kgm}^{-2}$. The entire seed bed was than divided into three seed beds and small plots $(50 \mathrm{~cm} \mathrm{X} 50 \mathrm{~cm}$ ) were prepared considering the 31 rice genotypes. Between the plots $10 \mathrm{~cm}$ distance was maintained. Drainage channels $(30 \mathrm{~cm})$ were prepared between seed beds to drain out excess water whenever needed. The seeds were soaked into water for 24 hours and incubated in moist cloth sacks for 48 hours for quick germination. The pre-germinated seeds were sown in seedbed on $29^{\text {th }}$ March, 2014.

\subsubsection{Experimental design}

Field experiments were conducted following randomized complete block design (RCBD) with three replications. Row to row and plant to plant distance were $20 \mathrm{~cm}$ and $15 \mathrm{~cm}$ respectively.

\subsubsection{Transplanting}

One seedling per hill was transplanted to the main plot on the $18^{\text {th }}$ April, 2014. Row to row and plant to plant distance were $20 \mathrm{~cm}$ and $15 \mathrm{~cm}$ respectively.

\subsubsection{Intercultural operations}

Gap filling was done within seven days after transplanting with the seedlings from same source to obtain uniform plant population. Drainage and weeding were done as and when required. Insecticides and fungicides were sprayed only once. No artificial irrigation was given.

\subsubsection{Harvesting}

Different genotypes were matured at different times. Harvesting was done when $90 \%$ of the plant populations of each plot reached to maturity.

\subsubsection{Recording of data}

Data were recorded on the following traits-Days to flowering, Days to maturity, Plant height, Total tillers hill ${ }^{-1}$, Effective tillers hill ${ }^{-1}$, Non effective tillers hill ${ }^{-1}$, Panicle length, Filled grains panicle ${ }^{-1}$, Unfilled grains panicle ${ }^{-1}$, 100-Seed weight (g), Yield plant ${ }^{-1}$. 
2.3. Estimation of genetic parameters

\subsubsection{Estimation of genotypic and phenotypic variances}

Genotypic and phenotypic variances were estimated according to the formula given by Johnson et al., (1995).

$$
\text { Genotypic variance, } \sigma_{\mathrm{g}}^{2}=\frac{\mathrm{GMS}-\mathrm{EMS}}{\mathrm{r}}
$$

Where, GMS = Genotypic mean square, EMS = Error mean square and $\mathrm{r}=$ Number of replication.

Phenotypic variance, $\sigma_{\mathrm{p}}^{2}=\sigma_{\mathrm{g}}^{2}+$ EMS

Where, $\sigma_{\mathrm{g}}^{2}=$ Genotypic variance and EMS = Error mean square

\subsubsection{Estimation of heritability}

Heritability in broad sense $\left(\mathrm{h}_{\mathrm{b}}{ }_{\mathrm{b}}\right)$ was estimated according to the formula suggested by Johnson et al., (1955) and Hanson et al., (1956).

Heritability, $\mathrm{h}_{\mathrm{b}}{ }^{2}=\frac{\sigma^{2} \mathrm{~g}}{\sigma_{\mathrm{p}} \mathrm{p}} \times 100$

Where, $\mathrm{h}_{\mathrm{b}}^{2}=$ Heritability in broad sense, $\sigma_{\mathrm{g}}^{2}=$ Genotypic variance; and $\sigma_{\mathrm{p}}^{2}=$ Phenotypic variance.

\subsubsection{Estimation of genotypic coefficient of variation (GCV) and phenotypic coefficient of variation} (PCV)

Genotypic and phenotypic coefficient of variations were estimated according to Burton (1952) and Singh and Chaudhury (1985).

$$
\text { Genotypic coefficient of variations, GCV }=\frac{\sqrt{\sigma_{\mathrm{g}}^{2}}}{\bar{X}} \times 100
$$

Where, $\sigma_{\mathrm{g}}^{2}=$ Genotypic variance and $\overline{\mathrm{X}}=$ Population mean

$$
\text { Phenotypic coefficient of variations, PCV }=\frac{\sqrt{\sigma_{\mathrm{P}}^{2}}}{\bar{X}} \times 100
$$

Where, $\sigma_{\mathrm{p}}^{2}=$ Phenotypic variance and $\overline{\mathrm{X}}=$ Population mean

\subsubsection{Estimation of genetic advance}

Estimation of genetic advance was done following formula given by Johnson et al., (1955) and Allard (1960).

Genetic advance, $\mathrm{GA}=\mathrm{h}_{\mathrm{b}}^{2} \cdot \mathrm{K} \cdot \sigma_{\mathrm{p}}$

Where, $\mathrm{h}_{\mathrm{b}}^{2}=$ Heritability in broad sense, $\mathrm{K}=$ Selection differential, the value of which is 2.06 at $5 \%$ selection intensity and $\sigma_{\mathrm{p}}=$ Phenotypic standard deviation.

\subsubsection{Estimation of genetic advance in percentage of mean, GA (\%)}

Genetic advance in per cent of mean was calculated by the formula of Comstock and Robinson (1952) as follows:

$$
\text { Genetic advance in percentage of mean, GA }(\%)=\frac{G A}{\bar{X}} \times 100
$$

Where, $\mathrm{GA}=$ Genetic advance and $\overline{\mathrm{X}}=$ Population mean

\section{Results and Discussion}

The analyses of variance of different NERICA mutant lines indicated that the difference among genotypes for all the quantitativetraits under study viz., days to flowering $\left(1^{\text {st }}, 50 \%, 80 \%\right)$, days to maturity, plant height $(\mathrm{cm})$, total tillers hill ${ }^{-1}$, panicle length $(\mathrm{cm})$, effective tillers hill ${ }^{-1}$, filled and unfilled grains panicle ${ }^{-1}, 100$ seed weight (g) and yield plant ${ }^{-1}(\mathrm{~g})$ were highly significant (Table.2). Yaqoob et al. (2012) observed significant variation among genotypes for days to maturity, total tillers hill $^{-1}$, effective tillers hill ${ }^{-1}$, plant height, panicle length, 100grain weight and yield plant ${ }^{-1}$. Tiwari et al. (2011) also observed significant variation among genotypes for days to $50 \%$ flowering, effective tillers plant ${ }^{-1}$, panicle length, and grain yield plant ${ }^{-1}$. These results suggest that all the genotypes under study had significant variation with each other.The mean performances of 31 rice genotypes for their morphological characters are shown in Table 3.

\subsection{Days to flowering $\left(1^{\text {st }}, 50 \%\right.$ and $\left.80 \%\right)$}

Being an important character to assess early maturity, days to flowering was taken to an account for the genotypes. Days to $1^{\text {st }}$ flowering among the genotypes ranged from 61.33 to 90.56 days with a mean value of 
77.67 days. $\mathrm{N}_{4} / 250 / \mathrm{P}-9-5-3$ took the lowest days to $1^{\text {st }}$ flowering (61.33 days) and $\mathrm{N}_{1}$ parent took the highest days to $1^{\text {st }}$ flowering (90.56 days). The average range of days to50\% flowering among the genotypes was 65.61 to 95.27 days with a mean value of 82.96 days. $\mathrm{N}_{4} / 250 / \mathrm{P}-9-5-3$ took the lowest days to $50 \%$ flowering (65.61 days) and $\mathrm{N}_{1}$ parent took the highest days to 50\% flowering (95.27days). Days to80\% flowering among the genotypes ranged from 70.43 to 101.7 days with a mean value of 88.53 days. $\mathrm{N}_{4} / 250 / \mathrm{P}-9-5-3$ took the lowest days to $80 \%$ flowering (70.43 days) and $\mathrm{N}_{1}$ parent took the highest days to $80 \%$ flowering (101.7 days).

\subsection{Days to maturity}

Early maturity is the most desirable character of rice variety in present situation. Days tomaturity among the genotypes ranged from 104.6 to 126.67 days with a mean value of 110.46 days. $\mathrm{N}_{1} / 250 / \mathrm{P}-7-3$ took the lowest days to maturity (104.6 days) which was followed by $\mathrm{N}_{4} / 350 / \mathrm{P}-2(1)-32-11, \mathrm{~N}_{4} / 250 / \mathrm{P}-2(5)-11-13$ and $\mathrm{N}_{1} / 300 / \mathrm{P}-$ 9-5 and $\mathrm{N}_{1}$ parent took the highest days to maturity (126.70 days) which was followed by $\mathrm{N}_{4}$ parent and $\mathrm{N}_{1} / 250 / \mathrm{P}-7-3-12$.

\subsection{Plant height (cm)}

Lower plant height is desirable in rice breeding. The average range of plant height among the genotypes was $73.43 \mathrm{~cm}$ to $114.77 \mathrm{~cm}$ with a mean value of $97.12 \mathrm{~cm} . \mathrm{N}_{4}$ parent had the lowest plant height $(73.43 \mathrm{~cm})$ and $\mathrm{N}_{1} / 300 /$ P-9-5-12 had the highest plant height $(114.77 \mathrm{~cm})$. Plant height in rice is a complex character and is the end product of several genetically controlled factors (Cheema et al., 1987). Reduction in plant height may improve their resistance to lodging and reduce substantial yield losses associated with this trait (Abbasi et al. 1995).

\subsection{Number of total tillers hill ${ }^{-1}$}

The higher number of tillers hill ${ }^{-1}$ is preferable for achieving high yield. In this study, the average number of tiller hill ${ }^{-1}$ ranged from6.33 to 19.0 with a mean value of $10.49 . \mathrm{N}_{14} / 350 / \mathrm{P}-2(1)-32-11$ had the maximum number of tillers hill ${ }^{-1}(19.0)$ andN $1 / 250 / P-7-13-12$ had the minimum number of tillers hill ${ }^{-1}(6.33)$ which was followed byN $\mathrm{N}_{10} / 300 / \mathrm{P}-3-7-3$.

\subsection{Number of effective tillershill ${ }^{-1}$}

The number of effective tillers hill ${ }^{-1}$ is directly related to grain yield. In this study the number of effective tillers hill $^{-1}$ ranged from 5.00 to 14.00 with a mean value of $833 . \mathrm{N}_{4} / 350 / \mathrm{P}-2(1)-32-11$ had maximum number of effective tillers hill ${ }^{-1}$ (14.0) and $\mathrm{N}_{10} / 300 / \mathrm{P}-3-7-3$ had minimum number of effective tillers hill ${ }^{-1}(5.0)$.

\subsection{Panicle length $(\mathrm{cm})$}

Panicle length is also an important yield contributing character since higher panicle length could provide higher grain numbers. Panicle length among the genotypes ranged from 20.60 to $31.13 \mathrm{~cm}$ with a mean value of 25.05 $\mathrm{cm} . \mathrm{N}_{1} / 250 / \mathrm{P}-7-3-11$ had the longest panicle $(31.13 \mathrm{~cm})$ and $\mathrm{N}_{4}$ parent had the lowest panicle length $(20.60 \mathrm{~cm})$.

\subsection{Number of filled grains panicle ${ }^{-1}$}

The yield of the plant is related to number of filled grains panicle ${ }^{-1}$ and it differed significantly among the lines. In this study the number of filled grain panicle ${ }^{-1}$ ranged from 61.0 to 127.0 with a mean value of $95.91 . \mathrm{N}_{4} / 350 / \mathrm{P}$ 2 (1)-32-11 had the highest number of filled grain panicle ${ }^{-1}$ (127.0) and $\mathrm{N}_{1} / 350 / \mathrm{P}-2-2-4$ had the lowest number filled grain panicle ${ }^{-1}(61.0)$.

\subsection{Number of unfilled grains panicle ${ }^{-1}$}

Less number of unfilled grains panicle ${ }^{-1}$ is a positive attribute towards higher yield. The number of unfilled grain panicle $^{-1}$ ranged from 17.0 to 42.33 with a mean value of $30.77 . \mathrm{N}_{10} / 300 / \mathrm{P}-3-7-1$ had the highest number of unfilled grain panicle ${ }^{-1}$ (42.33) and $\mathrm{N}_{1} / 250 / \mathrm{P}-7-13-15$ had the lowest number of unfilled grain panicle ${ }^{-1}(17.0)$.

\subsection{0 seed weight $(\mathrm{g})$}

There was a significant difference in 100 seed weight among the lines depending on the size and shape of grains. 100 seed weight ranged from $1.73 \mathrm{~g}$ to $3.03 \mathrm{~g}$ with a mean value of $2.47 \mathrm{~g}$. The highest 100 seed weight was recorded in $\mathrm{N}_{1} / 250 / \mathrm{P}-7-3-12$ (3.03 g) and $\mathrm{N}_{1} / 350 / \mathrm{P}-2-2-4$ had minimum 100 seed weight $(1.73 \mathrm{~g})$. 
3.10. Yield plant $^{-1}(\mathrm{~g})$

There was significant difference in yield plant $^{-1}$ among the studied lines. Yield plant ${ }^{-1}(\mathrm{~g})$ ranged from $6.15 \mathrm{~g}$ to $33.02 \mathrm{~g}$ with a mean value of $18.73 \mathrm{~g}$. $\mathrm{N}_{1} / 350 / \mathrm{P}-9-5$ had maximum yield plant ${ }^{-1}(33.02 \mathrm{~g})$ andN $\mathrm{N}_{1}$ parent and $\mathrm{N}_{4}$ parent had minimum yield plant ${ }^{-1}(6.15 \mathrm{~g})$.

3.11. Estimation of genetic parameters of NERICA mutant lines along with their parents

Genotypic variances, phenotypic variances, heritability, genotypic co-efficient of variation (GCV), phenotypic co-efficient of variation (PCV), genetic advance and genetic advance as percent of mean, GA (\%) for all the yield contributing traits are presented in Table 4.

Table 1. List of the genotypes used in the experiment.

\begin{tabular}{|c|c|c|}
\hline SI. No & Symbol & Genotypes \\
\hline 1 & G1 & $\mathrm{N}_{4} / 350 / \mathrm{P}-2(1)-32-11$ \\
\hline 2 & $\mathrm{G} 2$ & $\mathrm{~N}_{1} / 300 /$ P-9-9-13 \\
\hline 3 & G3 & $\mathrm{N}_{10} / 300 / \mathrm{P}-2(1)-11-(1)$ \\
\hline 4 & G4 & $\mathrm{N}_{1} / 350 / \mathrm{P}-2-2-4$ \\
\hline 5 & G5 & $\mathrm{N}_{1} / 250 / \mathrm{P}-7-2-1$ \\
\hline 6 & G6 & $\mathrm{N}_{10} / 300 / \mathrm{P}-2(1)-6-11$ \\
\hline 7 & G7 & $\mathrm{N}_{4} / 250 / \mathrm{P}-2(5)-11-13$ \\
\hline 8 & G8 & $\mathrm{N}_{10} / 300 / \mathrm{P}-3-7-1$ \\
\hline 9 & G9 & $\mathrm{N}_{10} / 300 / \mathrm{P}-3-7-3$ \\
\hline 10 & G10 & $\mathrm{N}_{10} / 300 / \mathrm{P}-5-7-5$ \\
\hline 11 & G11 & $\mathrm{N}_{4} / 250 / \mathrm{P}-2(6)-26(1,3,4)$ \\
\hline 12 & G12 & $\mathrm{N}_{4} / 300 / \mathrm{P}-3(4)-10-9$ \\
\hline 13 & G13 & $\mathrm{N}_{1} / 250 / \mathrm{P}-7-3-12$ \\
\hline 14 & G14 & $\mathrm{N}_{10} / 300 / \mathrm{P}-2-3-5$ \\
\hline 15 & G15 & $\mathrm{N}_{1} / 300 / \mathrm{P}-9-5-12$ \\
\hline 16 & G16 & $\mathrm{N}_{10} / 300 / \mathrm{P}-2(1)-8$ \\
\hline 17 & G17 & $\mathrm{N}_{4} / 250 / \mathrm{P}-2(5)-11-10$ \\
\hline 18 & G18 & $\mathrm{N}_{4} / 250 / \mathrm{P}-9-5-3$ \\
\hline 19 & G19 & $N_{1} / 250 / P-7-3-11$ \\
\hline 20 & G20 & $N_{1} / 250 / P-7-3-15$ \\
\hline 21 & $\mathrm{G} 21$ & $\mathrm{~N}_{1} / 250 / \mathrm{P}-7-3-12$ \\
\hline 22 & $\mathrm{G} 22$ & $\mathrm{~N}_{1} / 350 / \mathrm{P}-2-3$ \\
\hline 23 & $\mathrm{G} 23$ & $\mathrm{~N}_{1} / 300 / \mathrm{P}-9-5$ \\
\hline 24 & G24 & $\mathrm{N}_{10} / 300 / \mathrm{P}-3-7-6$ \\
\hline 25 & $\mathrm{G} 25$ & $\mathrm{~N}_{1} / 300 / \mathrm{P}-8-3-3$ \\
\hline 26 & G26 & $\mathrm{N}_{1} / 250 / \mathrm{P}-6-2-8$ \\
\hline 27 & G27 & $\mathrm{N}_{1} / 250 / \mathrm{P}-7-3$ \\
\hline 28 & $\mathrm{G} 28$ & $N_{1} / 300 / P-9-5-6$ \\
\hline 29 & G29 & $\mathrm{N}_{1}$ Parent \\
\hline 30 & G30 & $\mathrm{N}_{4}$ Parent \\
\hline 31 & G31 & $\mathrm{N}_{10}$ Parent \\
\hline
\end{tabular}

\subsubsection{Variability parameters}

A wide range of variation was observed among thirty one rice genotypes for eleven yield contributing traits. The perusal of data revealed that variance due to treatment was highly significant for all the traits (Table 2). This suggested that there were inherent genetic differences among the genotypes. Coefficient of variation studied indicated that phenotypic coefficient of variation (PCV) were higher than the corresponding genotypic coefficient of variation (GCV) for all the traits (Table 3) indicating that they all interacted with the environment to some extent. That means the studied traits are influenced by the environment. Among the all traits total tillers hill $^{-1}$ (26.20\% and $28.64 \%$ ) exhibited high estimates of genotypic coefficient of variation (GCV) and phenotypic coefficient of variation (PCV) respectively. On the other hand, Days to $1^{\text {st }}$ flowering $(8.13 \%$ and $8.46 \%)$, days to $50 \%$ flowering (7.67\% and $7.99 \%)$, days to $80 \%$ flowering $(7.34 \%$ and $7.62 \%)$, days to maturity $(4.20 \%$ and $5.12 \%)$ and plant height (10.48\% and $11.68 \%)$ exhibited low genotypic coefficient of variation (GCV) and phenotypic coefficient of variation (PCV). 
Table 2. Analysis of variance for different morphological plant characters of 31 NERICA mutant lines.

\begin{tabular}{|c|c|c|c|c|c|c|c|c|c|c|c|c|c|}
\hline Characters & d.f & $\begin{array}{l}\text { Days to 1st } \\
\text { flowering }\end{array}$ & $\begin{array}{l}\text { Days to } 50 \% \\
\text { flowering }\end{array}$ & $\begin{array}{l}\text { Days to } 80 \% \\
\text { flowering }\end{array}$ & $\begin{array}{l}\text { Days to } \\
\text { maturity }\end{array}$ & $\begin{array}{l}\text { Plant } \\
\text { height } \\
(\mathrm{cm})\end{array}$ & $\begin{array}{l}\text { Total } \\
\text { tillers hill }{ }^{-1}\end{array}$ & $\begin{array}{l}\text { Effective } \\
\text { tillers hill }\end{array}$ & $\begin{array}{l}\text { Panicle } \\
\text { Length } \\
\text { (cm) }\end{array}$ & $\begin{array}{l}\text { Filled grain } \\
\text { panicle }^{-1}\end{array}$ & $\begin{array}{l}\text { Unfilled grain } \\
\text { panicle }^{-1}\end{array}$ & $\begin{array}{l}\text { 100 Seed } \\
\text { weight } \\
\text { (g) }\end{array}$ & $\begin{array}{l}\text { Yield plant } \\
\text { (g) }\end{array}$ \\
\hline Genotypes & 30 & $122.95 * *$ & $124.86^{* *}$ & $129.93 * *$ & $74.97 * *$ & $335.62 * *$ & $24.15^{* *}$ & $13.68 * *$ & $23.29 * *$ & $769.68 * *$ & $129.56^{* *}$ & $0.335^{* *}$ & $154.29 * *$ \\
\hline Replication & 2 & 36.633 & 37.113 & 61.277 & 69.384 & 91.409 & 0.140 & 0.103 & 15.936 & 121.043 & 2.065 & 0.004 & 2.89 \\
\hline Error & 60 & 3.263 & 3.442 & 3.244 & 10.423 & 25.043 & 1.473 & 0.649 & 7.001 & 63.176 & 4.720 & 0.018 & 1.64 \\
\hline
\end{tabular}

Here,

d.f $=$ Degree of freedom

** indicates significant at 0.01 probability level.

$\mathrm{NS}=$ Not significant

Table 3. Mean performance of 31 rice genotypes on different morphological traits related to yield.

\begin{tabular}{|c|c|c|c|c|c|c|c|c|c|c|c|c|}
\hline Genotypes & $\begin{array}{l}\text { Days to } \\
\text { 1st } \\
\text { flowering }\end{array}$ & $\begin{array}{l}\text { Days to } \\
50 \% \\
\text { flowering }\end{array}$ & $\begin{array}{l}\text { Days to } \\
80 \% \\
\text { flowering }\end{array}$ & $\begin{array}{l}\text { Days to } \\
\text { maturity }\end{array}$ & $\begin{array}{l}\text { Plant } \\
\text { height } \\
\text { (cm) }\end{array}$ & $\begin{array}{l}\text { Total tiller } \\
\text { hill }^{-1}\end{array}$ & $\begin{array}{l}\text { Effective } \\
\text { tillers } \\
\text { hill }^{-1}\end{array}$ & $\begin{array}{l}\text { Panicle length } \\
\text { (cm) }\end{array}$ & $\begin{array}{l}\text { Filled grain } \\
\text { panicle }^{-1}\end{array}$ & $\begin{array}{l}\text { Unfilled } \\
\text { grain } \\
\text { panicle }^{-1}\end{array}$ & $\begin{array}{l}100 \text { Seed } \\
\text { weight } \\
\text { (g) }\end{array}$ & $\begin{array}{l}\text { Yield } \\
\text { plant }^{-1} \\
(\mathrm{~g})\end{array}$ \\
\hline N4/350/P-2(1)-32-11 & $73.57 \mathrm{gh}$ & $78.17 \mathrm{jkl}$ & $84.51 \mathrm{hi}$ & $105.5 \mathrm{f}$ & 103.3bcde & $19.00 \mathrm{a}$ & $14.00 \mathrm{a}$ & 25.67cdefghi & $127.0 \mathrm{a}$ & $39.00 \mathrm{abc}$ & 2.43 fghi & $31.46 \mathrm{a}$ \\
\hline N1/300/P-9-9-13 & $75.33 \mathrm{efg}$ & 80.66hijk & $86.33 \mathrm{fgh}$ & $107.7 \mathrm{def}$ & 93.67fghij & $16.67 \mathrm{~b}$ & $12.67 \mathrm{~b}$ & 26.00bcdefgh & 90.00fghijkl & 26.67hi & 2.24hijk & $25.09 \mathrm{~d}$ \\
\hline N10/300/P-2(1)-11-(1) & $67.52 \mathrm{i}$ & $72.34 \mathrm{~m}$ & $78.38 \mathrm{k}$ & $107.7 \mathrm{def}$ & $105.6 \mathrm{abcd}$ & $16.00 \mathrm{~b}$ & $10.33 c$ & 24.00defghi & 96.00efghijk & $24.33 \mathrm{ijk}$ & $1.891 \mathrm{~m}$ & $20.85 f g$ \\
\hline $\mathrm{N} 1 / 350 / \mathrm{P}-2-2-4$ & $71.43 \mathrm{~h}$ & 76.531 & $80.43 \mathrm{jk}$ & $109.3 \mathrm{cdef}$ & $84.47 \mathrm{jk}$ & 10.00defghi & 7.67efg & 21.00hi & $61.00 n$ & $33.67 \mathrm{ef}$ & $1.73 \mathrm{~m}$ & $12.36 \mathrm{jk}$ \\
\hline $\mathrm{N} 1 / 250 / \mathrm{P}-7-2-1$ & $79.07 \mathrm{~cd}$ & $84.62 \mathrm{efg}$ & $90.60 \mathrm{cde}$ & $108.2 \mathrm{def}$ & $86.50 \mathrm{ijk}$ & 10.67defgh & $8.33 \mathrm{def}$ & 21.30ghi & $85.67 \mathrm{ijl}$ & 37.33bcde & $2.92 \mathrm{ab}$ & $19.01 \mathrm{~g}$ \\
\hline N10/300/P-2(1)-6-11 & $66.70 \mathrm{i}$ & $71.70 \mathrm{~m}$ & $77.95 \mathrm{k}$ & $109.7 \mathrm{cdef}$ & $88.70 \mathrm{ij}$ & $11.67 \mathrm{de}$ & $9.67 \mathrm{~cd}$ & 23.70defghi & $114.3 \mathrm{abc}$ & $22.00 \mathrm{jkl}$ & $1.77 \mathrm{~m}$ & $16.44 \mathrm{~h}$ \\
\hline N4/250/P-2(5)-11-13 & $80.20 \mathrm{~cd}$ & 86.70de & $93.00 \mathrm{bc}$ & $105.7 f$ & 106.7abcd & 10.33defghi & $8.33 \mathrm{def}$ & 20.77hi & $85.00 \mathrm{ijklm}$ & $38.00 \mathrm{bcd}$ & 2.59defg & $16.26 \mathrm{~h}$ \\
\hline N10/300/P-3-7-1 & $74.26 \mathrm{fgh}$ & 80.60hijk & 86.33fgh & $110.3 \mathrm{cdef}$ & 93.63fghij & 11.00defg & $9.00 \mathrm{cde}$ & 26.60abcdefg & $111.7 \mathrm{bcd}$ & $42.33 \mathrm{a}$ & 2.31hij & $29.30 \mathrm{~b}$ \\
\hline N10/300/P-3-7-3 & $72.43 \mathrm{gh}$ & $77.33 \mathrm{kl}$ & $82.50 \mathrm{ij}$ & $109.6 \mathrm{cdef}$ & $89.63 \mathrm{ij}$ & $6.67 \mathrm{kl}$ & $5.00 \mathrm{j}$ & 25.30defghi & 101.3cdefgh & $31.33 \mathrm{fg}$ & $2.02 \mathrm{kl}$ & $12.47 \mathrm{jk}$ \\
\hline $\mathrm{N} 10 / 300 / \mathrm{P}-5-7-5$ & 78.37cde & $82.66 f g h$ & $88.27 \mathrm{defg}$ & $108.8 \mathrm{def}$ & 91.63ghij & $9.00 \mathrm{fgh}$ & $7.00 \mathrm{fgh}$ & 25.00 & $102.7 \mathrm{cdefg}$ & 26.33hi & 2.28hij & $13.65 \mathrm{ijk}$ \\
\hline $\begin{array}{l}\text { N4/250/P-2(6)- } \\
26(1,3,4)\end{array}$ & 80 & $\varepsilon$ & 90.33 cde & 107.3def & $109.5 \mathrm{abc}$ & 11.33def & 0 & 22.33efghi & 104.0cdef & ii & 1 & g \\
\hline N4/300/P-3(4)-10-9 & $80.58 \mathrm{~cd}$ & $85.30 \mathrm{ef}$ & $92.73 b c$ & $110.0 c 40$ & 104.6bcde & 11.00defg & 8.3 & 24.70 & $103.0 \mathrm{cdefg}$ & $25.00 \mathrm{ijk}$ & $2.73 \mathrm{bcde}$ & $27.42 b c$ \\
\hline $\mathrm{N} 1 / 250 / \mathrm{P}-7-3-12$ & $78.40 \mathrm{cde}$ & 83.46efgh & 89.67cdef & $115.4 b c$ & 101.0cdefg & 9.00fghijk & 7.00fgh & 26.80abcdef & $84.33 \mathrm{jklm}$ & $31.33 \mathrm{fg}$ & $3.03 \mathrm{a}$ & $20.34 \mathrm{fg}$ \\
\hline N10/300/P-2-3-5 & $75.28 \mathrm{efg}$ & 81.50ghij & 86.33fgh & $113.6 \mathrm{bcd}$ & 95.33efghi & 8.67ghijkl & 7.00fgh & 26.03bcdefgh & $118.7 \mathrm{ab}$ & 34.00def & $2.50 \mathrm{efgh}$ & $20.57 f g$ \\
\hline N1/300/P-9-5-12 & $77.33 \mathrm{def}$ & 82.38fghi & $87.25 \mathrm{efgh}$ & 107.0ef & $114.8 \mathrm{a}$ & $7.33 \mathrm{jkl}$ & 6.00hij & 24.70defghi & 103.7cdef & $30.00 \mathrm{fgh}$ & $2.81 \mathrm{abcd}$ & $12.48 \mathrm{jk}$ \\
\hline N10/300/P-2(1)-8 & $79.42 \mathrm{~cd}$ & $84.67 \mathrm{efg}$ & $89.05 \mathrm{defg}$ & $112.6 \mathrm{bcde}$ & $109.3 \mathrm{abc}$ & 8.00ijkl & $6.000 \mathrm{hij}$ & $30.87 \mathrm{ab}$ & $74.33 \mathrm{mn}$ & $37.67 \mathrm{bcde}$ & $2.35 \mathrm{ghij}$ & $12.85 \mathrm{jk}$ \\
\hline $\mathrm{N} 4 / 250 / \mathrm{P}-2(5)-11-10$ & $78.17 \mathrm{cde}$ & $84.57 \mathrm{efg}$ & $90.33 \mathrm{cde}$ & $108.5 \mathrm{def}$ & $111.9 \mathrm{ab}$ & 9.33efghij & 6.67ghi & 25.23defghi & $126.3 \mathrm{a}$ & $19.001 \mathrm{~m}$ & $2.85 \mathrm{abc}$ & 23.96de \\
\hline $\mathrm{N} 4 / 250 / \mathrm{P}-9-5-3$ & $61.33 \mathrm{j}$ & $65.61 n$ & 70.431 & $109.4 \mathrm{cdef}$ & $88.13 \mathrm{ij}$ & $8.00 \mathrm{ijkl}$ & $7.33 \mathrm{fgh}$ & 25.70cdefghi & $119.7 \mathrm{ab}$ & $36.33 \mathrm{cde}$ & $2.44 \mathrm{fgh}$ & $13.16 \mathrm{ijk}$ \\
\hline
\end{tabular}




\begin{tabular}{|c|c|c|c|c|c|c|c|c|c|c|c|c|}
\hline Genotypes & $\begin{array}{l}\text { Days to } 1 \text { st } \\
\text { flowering }\end{array}$ & $\begin{array}{l}\text { Days to } \\
50 \% \\
\text { flowering }\end{array}$ & $\begin{array}{l}\text { Days to } \\
80 \% \\
\text { flowering }\end{array}$ & $\begin{array}{l}\text { Days to } \\
\text { maturity }\end{array}$ & $\begin{array}{l}\begin{array}{l}\text { Plant } \\
\text { height } \\
\text { (cm) }\end{array} \\
\end{array}$ & $\begin{array}{l}\text { Total tiller } \\
\text { hill }^{-1}\end{array}$ & $\begin{array}{l}\text { Effective } \\
\text { tillers } \\
\text { hill }^{-1} \\
\end{array}$ & $\begin{array}{l}\text { Panicle } \\
\text { length } \\
(\mathrm{cm})\end{array}$ & $\begin{array}{l}\text { Filled grain } \\
\text { panicle }^{-1}\end{array}$ & $\begin{array}{l}\text { Unfilled } \\
\text { grain } \\
\text { panicle }^{-1}\end{array}$ & $\begin{array}{l}\text { 100 Seed } \\
\text { weight } \\
\text { (g) }\end{array}$ & $\begin{array}{l}\text { Yield } \\
\text { plant }^{-1} \\
(\mathrm{~g})\end{array}$ \\
\hline $\mathrm{N} 1 / 250 / \mathrm{P}-7-3-11$ & $81.23 \mathrm{c}$ & $86.47 \mathrm{de}$ & 90.33 cde & 108.6def & 107.7abcd & 8.67ghijkl & $7.33 \mathrm{fgh}$ & $31.13 \mathrm{a}$ & $81.00 \mathrm{klm}$ & $30.67 \mathrm{fg}$ & 2.33ghij & $13.10 \mathrm{ijk}$ \\
\hline N1/250/P-7-13-15 & $74.33 \mathrm{fgh}$ & $79.00 \mathrm{ijkl}$ & 84.61hi & $107.8 \mathrm{def}$ & $105.0 \mathrm{bcde}$ & 8.33hijkl & 6.00hij & 24.97defghi & $78.671 \mathrm{~m}$ & $17.00 \mathrm{~m}$ & 2.72 bcde & 14.36hij \\
\hline $\mathrm{N} 1 / 250 / \mathrm{P}-7-13-12$ & $85.34 \mathrm{~b}$ & $89.53 \mathrm{~cd}$ & $95.67 \mathrm{~b}$ & $112.6 \mathrm{bcde}$ & $88.50 \mathrm{ij}$ & 6.331 & $5.33 \mathrm{ij}$ & 26.77abcdef & 84.67ijklm & $31.33 \mathrm{fg}$ & $2.69 \mathrm{bcde}$ & $11.80 \mathrm{kl}$ \\
\hline $\mathrm{N} 1 / 350 / \mathrm{P}-2-3$ & $75.40 \mathrm{efg}$ & 80.67hijk & $86.50 f g h$ & $110.6 \mathrm{cdef}$ & 95.37efghi & $12.33 \mathrm{~cd}$ & $9.33 \mathrm{~cd}$ & 23.73defghi & 87.00hijklm & $21.33 \mathrm{kl}$ & $2.72 \mathrm{bcde}$ & $21.39 \mathrm{f}$ \\
\hline N1/300/P-9-5 & $84.37 \mathrm{~b}$ & $90.69 \mathrm{bc}$ & $95.27 \mathrm{~b}$ & $105.9 \mathrm{f}$ & $104.8 \mathrm{bcde}$ & $14.00 \mathrm{c}$ & $12.33 \mathrm{~b}$ & 24.93defghi & 99.00defghij & $25.67 \mathrm{ij}$ & $2.80 \mathrm{abcd}$ & $33.02 \mathrm{a}$ \\
\hline N10/300/P-3-7-6 & $80.41 \mathrm{~cd}$ & $86.33 \mathrm{de}$ & $91.48 \mathrm{~cd}$ & 107.6def & 104.5 bcde & 10.00defghi & $8.33 \mathrm{def}$ & $30.43 \mathrm{abc}$ & 92.33fghijkl & $32.33 \mathrm{f}$ & 2.38ghij & 15.26hi \\
\hline $\mathrm{N} 1 / 300 / \mathrm{P}-8-3-3$ & 75.33efg & $82.73 \mathrm{fgh}$ & 88.27defg & $110.8 \mathrm{cdef}$ & 102.3bcdef & $11.33 \mathrm{def}$ & $9.67 \mathrm{~cd}$ & 24.83defghi & 100.0cdefghi & $30.67 f g$ & $2.75 \mathrm{bcde}$ & $21.99 \mathrm{ef}$ \\
\hline N1/250/P-6-2-8 & $74.58 \mathrm{fgh}$ & $80.00 \mathrm{hijk}$ & $85.67 \mathrm{ghi}$ & 109.3cdef & 103.0bcdef & 11.00defg & $9.00 \mathrm{cde}$ & 28.87abcd & 97.00defghij & $38.00 \mathrm{bcd}$ & $2.66 \mathrm{bcdef}$ & 23.60de \\
\hline $\mathrm{N} 1 / 250 / \mathrm{P}-7-3$ & $80.17 \mathrm{~cd}$ & $85.60 \mathrm{ef}$ & $90.33 \mathrm{cde}$ & $104.6 \mathrm{f}$ & 91.37hij & 10.67defgh & $9.67 \mathrm{~cd}$ & 27.23abcde & $110.0 \mathrm{bcde}$ & $31.67 f$ & $2.77 \mathrm{bcd}$ & $28.73 b$ \\
\hline N1/300/P-9-5-6 & $90.48 \mathrm{a}$ & $94.67 \mathrm{a}$ & $99.85 \mathrm{a}$ & $110.5 \mathrm{cdef}$ & 99.27 defgh & $11.67 \mathrm{de}$ & $10.33 \mathrm{c}$ & 22.90efghi & 94.33fghijk & $37.00 \mathrm{bcde}$ & $2.64 \mathrm{cdef}$ & $25.85 \mathrm{~cd}$ \\
\hline N1 parent & $90.56 \mathrm{a}$ & $95.27 \mathrm{a}$ & $101.7 \mathrm{a}$ & $126.7 \mathrm{a}$ & $79.00 \mathrm{kl}$ & 8.33hijkl & 7.33fgh & 21.67fghi & 88.00ghijklm & $32.33 f$ & 2.28hij & $6.640 \mathrm{~m}$ \\
\hline $\mathrm{N} 4$ parent & $88.33 a$ & $93.60 \mathrm{ab}$ & $99.83 \mathrm{a}$ & $125.3 \mathrm{a}$ & 73.431 & 10.33defghi & $7.33 \mathrm{fgh}$ & $20.60 \mathrm{i}$ & $74.00 \mathrm{mn}$ & $23.33 \mathrm{ijk}$ & $2.17 \mathrm{ijk}$ & $6.153 \mathrm{~m}$ \\
\hline N10 parent & $77.65 \mathrm{def}$ & 83.17 efgh & $90.67 \mathrm{cde}$ & $117.3 \mathrm{~b}$ & $78.13 \mathrm{kl}$ & 8.67ghijkl & 6.33ghij & 22.70efghi & $78.671 \mathrm{~m}$ & $41.00 \mathrm{ab}$ & 2.42 fghi & 9.9701 \\
\hline CV $(\%)$ & 2.33 & 2.24 & 2.03 & 2.92 & 5.15 & 11.57 & 9.67 & 10.56 & 8.29 & 7.06 & 5.45 & 6.84 \\
\hline Maximum & 90.56 & 95.27 & 101.67 & 126.67 & 114.77 & 19.00 & 14.00 & 31.13 & 127.00 & 42.33 & 3.03 & 33.02 \\
\hline Minimum & 61.33 & 65.61 & 70.43 & 104.60 & 73.43 & 6.33 & 5.00 & 20.60 & 61.00 & 17.00 & 1.73 & 6.15 \\
\hline Mean & 77.67 & 82.96 & 88.53 & 110.46 & 97.12 & 10.49 & 8.33 & 25.05 & 95.91 & 30.77 & 2.47 & 18.73 \\
\hline $\mathbf{L S D}_{(0.05)}$ & 2.95 & 3.03 & 2.94 & 5.27 & 8.17 & 1.98 & 1.32 & 4.32 & 12.98 & 3.55 & 0.219 & 2.09 \\
\hline
\end{tabular}

Notes: Genotypes with the different letter(s) are significantly different.

Table 4. Estimation of genetic parameters for morphological characters related to yield.

\begin{tabular}{|c|c|c|c|c|c|c|c|c|}
\hline $\begin{array}{l}\text { SL. } \\
\text { No. }\end{array}$ & Characters & $\begin{array}{l}\text { Phenotypic } \\
\text { variance }\left(\sigma_{p}^{2}\right)\end{array}$ & $\begin{array}{l}\text { Genotypic } \\
\text { variance }\left(\sigma_{g}^{2}\right)\end{array}$ & $\operatorname{PCV}(\%)$ & $\operatorname{GCV}(\%)$ & Heritability (\%) & GA & GA (\%) \\
\hline 1 & Days to $1^{\text {st }}$ flowering & 43.16 & 39.90 & 8.46 & 8.13 & 92.44 & 12.51 & 16.11 \\
\hline 2 & Days to $50 \%$ flowering & 43.92 & 40.47 & 7.99 & 7.67 & 92.16 & 12.58 & 15.16 \\
\hline 3 & Days to $80 \%$ flowering & 45.47 & 42.33 & 7.62 & 7.34 & 92.87 & 12.90 & 14.57 \\
\hline 4 & Days to maturity & 31.94 & 21.52 & 5.12 & 4.20 & 67.37 & 7.84 & 7.10 \\
\hline 5 & Plant height (cm) & 128.57 & 103.53 & 11.68 & 10.48 & 80.52 & 18.81 & 19.37 \\
\hline 6 & Total tillers hill $^{-1}$ & 9.03 & 7.56 & 28.64 & 26.20 & 83.69 & 5.18 & 49.37 \\
\hline 7 & Effective tillers hill ${ }^{-1}$ & 5.00 & 4.35 & 26.82 & 25.02 & 87.01 & 4.01 & 48.07 \\
\hline 8 & Panicle length(cm) & 12.43 & 5.43 & 14.08 & 9.30 & 43.68 & 3.17 & 12.67 \\
\hline 9 & Filled grain panicle ${ }^{-1}$ & 298.68 & 235.50 & 18.02 & 16.00 & 78.85 & 28.07 & 29.27 \\
\hline 10 & Unfilled grain panicle $^{-1}$ & 46.33 & 41.61 & 22.12 & 20.96 & 89.81 & 12.59 & 40.92 \\
\hline 11 & 100 Seed weight $(\mathrm{g})$ & 0.124 & 0.106 & 14.26 & 13.19 & 85.44 & 0.61 & 25.11 \\
\hline
\end{tabular}

Notes: $\mathrm{PCV}=$ Phenotypic coefficient of variation, $\mathrm{GCV}=$ Genotypic coefficient of variation, $\mathrm{GA}=$ Genetic advance, GA $(\%)=$ Genetic advance as percent of mean 
The high values of genotypic coefficient of variation (GCV) and phenotypic coefficient of variation (PCV) for these traits suggested the possibility of yield improvement through selection of these traits. Tiwari et al. (2011) also observed the higher magnitude of PCV and GCV for grain yield plant ${ }^{-1}$, number of fertile spikelets, effective tillers hill ${ }^{-1}$, panicle length and number of spikelets panicle ${ }^{-1}$.

\subsubsection{Heritability}

The estimates of heritability act as predictive instrument in expressing the reliability of phenotypic value. Therefore, high heritability helps in effective selection for a particular trait. Heritability was classified as low (below 30\%), medium (30-60\%) and high (above 60\%) as suggested by Johnson et al. (1955). The traits expressed moderate to high heritability estimates ranging from $43.68 \%$ to $92.87 \%$. Among the traits, high heritability was recorded by days to $80 \%$ flowering $(92.87 \%)$, days to $1^{\text {st }}$ flowering $(92.44 \%)$, days to $50 \%$ flowering $(92.16 \%)$, unfilled grain panicle ${ }^{-1}(89.81 \%)$, effective tillers hill ${ }^{-1}(87.01 \%), 100$ seed weight $(85.44 \%)$, total tillers hill ${ }^{-1}(83.69 \%)$, plant height $(80.52 \%)$, filled grain panicle ${ }^{-1}(78.85 \%)$ and days to maturity $(67.37 \%)$, and moderate heritability value was recorded bypanicle length (43.68\%) (Table4).High heritability values indicate that the traits under study are less influenced by environment in their expression and have greater possibility of genetic improvement through selection methods. Patel et al. (2012) observed highest heritability for days to $50 \%$ flowering, plant height, total tillers, panicle length, total number of spikelets panicle ${ }^{1}$, number of filled spikelets panicle ${ }^{-1}$, number of unfilled spikelets panicle ${ }^{-1}$ and grain yield $\mathrm{m}^{-2}$.

\subsubsection{Genetic advance}

The genetic advance is a useful indicator of the progress that can be expected as result of exercising selection on the pertinent population. Heritability in conjunction with genetic advance would give a more reliable index of selection value (Johnson et al., 1955). In the present study genetic advance was highest for number of filled grains panicle $^{-1}$ (28.07) and lowest for 100 seed weight (0.619) among yield contributing traits (Table 4).The genetic advance as percent of mean was highest in case of number of total tillers hill ${ }^{-1}(49.37 \%)$, while lowest recorded by days to maturity (7.10\%). Babu et al. (2012) also found highest genetic advance for number of filled grains panicle ${ }^{-1}$ and highest genetic advance as per cent of mean in case of number of unfilled grains panicle ${ }^{-1}$.

\section{Conclusions}

A total of 31 NERICA rice genotypes were evaluated for morphological characters and various genetic parameters were assessed. Considering the traits days to flowering and days to maturity, the genotype $\mathrm{N}_{4} / 250 / \mathrm{P}$ 9-5-3 was earliest (104.6 days) and $\mathrm{N}_{1}$ parent took highest days (126.7 days). All parents took the highest days to maturity than different lines. In terms of yield plant ${ }^{-1}$ genotype $\mathrm{N}_{1} / 300 / \mathrm{P}-9-5$ was superior $(33.02 \mathrm{~g})$ and $\mathrm{N}_{4}$ parent had minimum yield plant $^{-1}(6.15 \mathrm{~g})$. All the traits are highly influenced by the environment as PCV were higher than GCV and a little scope for genetic improvement. Days to $80 \%$, days to $1^{\text {st }}$ flowering, days to $50 \%$ flowering, number of unfilled grain panicle ${ }^{-1}$ and 100 seed weight are less influenced by environment in their expression. The lowest heritability value was recorded for panicle length. In the present study, high heritability along with high genetic advance was noticed for the traits, number of filled grain per panicle, plant height and days to 50\% flowering. These traits can be improved through simple or progeny selection methods. Other traits showed high heritability along with moderate or low genetic advance which can be improved by inter mating superior genotypes of segregating population developed from combination breeding. So, while taking breeding program using this genotype, higher emphasize should be given to environmental factors as well as agronomic practices.

\section{Conflict of interest}

None to declare.

\section{Reference}

Abbasi FM, MA Sagar, M Akram and M Ashraf, 1995. Agronomic and quality traits of some elite rice genotypes. Pak. J. Sci. and Ind. Res., 38:348-350.

Allard RW, 1960. Principles of Plant Breeding, John Wiley and Sons, Inc., New York. pp. 145.

Azad MAK, MI Uddin and MA Azam, 2012. Achievements in Rice research at BINA through Induced mutation. Global Science Books: Bioremediation, Biodiversity and Bioavailability. 6: 53-57.

Babu VR, K Shreya, KS Dangi, G Usharani and P Nagesh, 2012. Genetic variability studies for qualitative and quantitative traits in popular rice (Oryzasativa L.) hybrids of India. Int. J. Sci. and Res. Pub., 2:15. 
Burton GW, 1952. Quantitative inheritance in Grasses. $6^{\text {th }}$ international Grassland Congress. 1: 277-283.

Cheema AA, MA Awan and J Iqbal, 1987. Improvement of plant height architecture in basmati rice. Pak. J. Sci. and Ind. Res., 8:371-374.

Comstock RE, HF Robinson, 1952.Genetic parameters, their estimation and significance. $6^{\text {th }}$ international Grassland Congress. 1:284-291.

Das ML, A Rahman and MA Malek, 1999. Two Early Maturing and High Yielding Rapeseed Varieties Developed through Induced Mutation. Ban. J. Bot., 28: 27-33.

Johnson HW, HF Robinson and RE Comstock, 1955. Estimation of genetic and environmental variability in soybean.J. Agron., 47: 314-318.

Hanson G, HF Robinson and RE Comstock, 1956. Biometrical studies on yield in segregating population of Korean Lespedeza. J. Agron., 48: 268-274.

Mzengeza T, 2010. Genetic Studies of Grain and Morphological Traits in Early Generation Crosses of Malawi Rice (Oryzasativa L.) Landraces and NERICA Varieties, PhD Thesis, Department of Plant Breeding, Faculty of Science and Agriculture, University of KwaZulu-Natal, Republic of South Africa.

Patel A, PR Chaudhari and SB Verulkar, 2012.Analysis of genetic variability, heritability and genetic advance for yield and yield components in rice (Oryzasativa L.) under different water regimes. Plant Archives., 12: 425-435.

Shahidullah SM, MM Hanafi, M Ashrafuzzaman,MR Ismail and A Khair, 2009. Genetic diversity in grain quality and nutrition of aromatic rice. Afr. J. Biotechnol., 8:1238-1246.

Singh RK and BD Choudhury, 1985.Biometrical method in quantitative genetic analysis.Kalyani Publishers, Ludhiana, New Delhi, India.pp. 318.

Tiwari DK, P Pandey, S Tripathi, SP Giri and JL Dwivedi, 2011. Studies on genetic variability for yield components in rice. AAB Bioflux., 3: 76-81.

UBINIG, 2012.A discussion meeting on NERICA rice and Btbrinjal organized by UBINIG on 17 September 2012.

WARDA (West Africa Rice Development Association), 2008: Rice Interspecific Hybridization Project: Research Highlights 2008, WARDA, Bouaké, Côted'Ivoire. pp. 36.

Yaqoob M, N Hussain and A Rashid, 2012. Assessment of genetic variability in rice (OryzasativaL.) genotypes under rain fed conditions. J. Agril. Res., 50: 311-319. 